\title{
Chronic exposure of the freshwater alga Pseudokirchneriella subcapitata to five oxide nanoparticles: Hazard assessment and cytotoxicity mechanisms
}

\author{
Cátia A. Sousa ${ }^{\mathrm{a}, \mathrm{b}, \mathrm{c}}$, Helena M.V.M. Soares ${ }^{\mathrm{c}, *}$, Eduardo V. Soares ${ }^{\mathrm{a}, \mathrm{b}, *}$

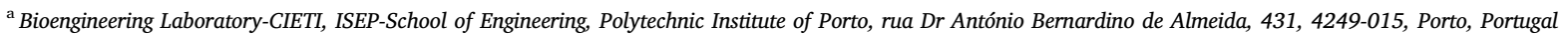 \\ ${ }^{\mathrm{b}}$ CEB-Centre of Biological Engineering, University of Minho, Campus de Gualtar, 4710-057, Braga, Portugal \\ ${ }^{\mathrm{c}}$ REQUIMTE/LAQV, Departamento de Engenharia Química, Faculdade de Engenharia, Universidade do Porto, rua Dr Roberto Frias, s/n, 4200-465, Porto, Portugal
}

\section{A R T I C L E I N F O}

\section{Keywords:}

Metabolic (esterase) activity

Microalga

Nanomaterials

Nanotoxicity

Oxidative stress

Photosynthesis

\begin{abstract}
A B S T R A C T
The increasing use of nanoparticles (NPs) unavoidably enhances their unintended introduction into the aquatic systems, raising concerns about their nanosafety. This work aims to assess the toxicity of five oxide $\mathrm{NPs}_{2}\left(\mathrm{Al}_{2} \mathrm{O}_{3}\right.$, $\mathrm{Mn}_{3} \mathrm{O}_{4}, \mathrm{In}_{2} \mathrm{O}_{3}, \mathrm{SiO}_{2}$ and $\mathrm{SnO}_{2}$ ) using the freshwater alga Pseudokirchneriella subcapitata as a primary producer of ecological relevance. These NPs, in OECD medium, were poorly soluble and unstable (displayed low zeta potential values and presented the tendency to agglomerate). Using the algal growth inhibition assay and taking into account the respective $72 \mathrm{~h}-\mathrm{EC}_{50}$ values, it was possible to categorize the NPs as: toxic $\left(\mathrm{Al}_{2} \mathrm{O}_{3}\right.$ and $\left.\mathrm{SnO}_{2}\right)$; harmful $\left(\mathrm{Mn}_{3} \mathrm{O}_{4}\right.$ and $\left.\mathrm{SiO}_{2}\right)$ and non-toxic/non-classified $\left(\mathrm{In}_{2} \mathrm{O}_{3}\right)$. The toxic effects were mainly due to the NPs, except for $\mathrm{SnO}_{2}$ which toxicity can mainly be attributed to the $\mathrm{Sn}$ ions leached from the NPs. A mechanistic study was undertaken using different physiological endpoints (cell membrane integrity, metabolic activity, photosynthetic efficiency and intracellular ROS accumulation). It was observed that $\mathrm{Al}_{2} \mathrm{O}_{3}, \mathrm{Mn}_{3} \mathrm{O}_{4}$ and $\mathrm{SiO}_{2}$ induced an algistatic effect (growth inhibition without loss of membrane integrity) most likely as a consequence of the cumulative effect of adverse outcomes: i) reduction of the photosynthetic efficiency of the photosystem II ( $\left.\Phi_{\mathrm{PSII}}\right)$; ii) intracellular ROS accumulation and iii) loss of metabolic activity. $\mathrm{SnO}_{2} \mathrm{NPs}$ also provoked an algistatic effect probably as a consequence of the reduction of $\Phi_{\mathrm{PSII}}$ since no modification of intracellular ROS levels and metabolic activity were observed. Altogether, the results here presented allowed to categorize the toxicity of the five NPs and shed light on the mechanisms behind NPs toxicity in the green alga $P$. subcapitata.
\end{abstract}

\section{Introduction}

In the emerging field of nanotechnology, the nanoparticles (NPs) exhibit unique physical and chemical properties due to their limited size $(<100 \mathrm{~nm}$ ). Metal(loid) oxide (MOx) NPs, such as aluminium oxide $\left(\mathrm{Al}_{2} \mathrm{O}_{3}\right)$, indium oxide $\left(\mathrm{In}_{2} \mathrm{O}_{3}\right)$, manganese oxide $\left(\mathrm{Mn}_{3} \mathrm{O}_{4}\right)$, silicon dioxide $\left(\mathrm{SiO}_{2}\right)$ and tin(IV) oxide $\left(\mathrm{SnO}_{2}\right)$ can be used in a wide range of fields, such as optics, electric and electronics, medical imaging, cosmetics, plastic production, ceramics, fuel additives and aerospace industry (Andreescu et al., 2012; Laurent et al., 2018; Nanotech, 2015; Tian et al., 2013; Vranic et al., 2019); for a more detailed description of the possible uses of these NPs, the reader can consult the table S1.

The safe use of nanotechnology, on an industrial scale, requires a careful evaluation of the potential environmental and human health risks that can result from the release of NPs into the environment. The increasing use of NPs inevitably intensifies their unintended introduction into the environment. Thus, the toxicity data of NPs are very important for the risk evaluation in aquatic environments. Algae, as primary producers, represent the base of food chain (first trophic level). Therefore, due to their ecological importance, universal distribution and sensitivity to a wide variety of toxicants, the alga Pseudokirchneriella subcapitata have been used in the assessment of toxicity (algal growth inhibition assay) (Geis et al., 2000; OECD, 2011; US-EPA, 2002).

Studies carried out in the last decade evidence that NPs, including MOx NPs can cause toxic effects. In this context, it was described that $\mathrm{Al}_{2} \mathrm{O}_{3}$ NPs caused growth inhibition and reduction of chlorophyll content in the green algae Chlorella sp. and Scenedesmus sp. (Sadiq et al., 2011) and in the red alga Porphyridium aerugineum Geitler (Karunakaran et al., 2015). $\mathrm{SiO}_{2}$ NPs inhibited the growth of the marine algae Dunaliella tertiolecta (Manzo et al., 2015); similarly, growth inhibition, reduction of chlorophyll and protein content in Porphyridium aerugineum Geitler exposed to $\mathrm{SiO}_{2} \mathrm{NPs}$ was described (Karunakaran et al., 2015). Aruoja et al. (2015) showed that $\mathrm{Al}_{2} \mathrm{O}_{3}, \mathrm{Mn}_{3} \mathrm{O}_{4}$ and $\mathrm{SiO}_{2}$

\footnotetext{
* Corresponding authors.

E-mail addresses: hsoares@fe.up.pt (H.M.V.M. Soares), evs@isep.ipp.pt (E.V. Soares).
} 
NPs caused growth inhibition of the alga $P$. subcapitata. Nonetheless, $\mathrm{Al}_{2} \mathrm{O}_{3}, \mathrm{In}_{2} \mathrm{O}_{3}$ and $\mathrm{SnO}_{2}$ NPs seem to be nontoxic to the marine diatom Skeletonema costatum ( $\mathrm{Ng}$ et al., 2015).

Despite the commercial importance of metal(loid)-based NPs, a limited information can be found in the literature regarding the potential ecotoxicity of the NPs studied, namely: i) the hazard evaluation; ii) the understanding of the mechanisms behind NPs toxicity. In this sense, this work aimed to assess the ecotoxicity (assessment and categorization of NP hazards) of five NPs $\left(\mathrm{Al}_{2} \mathrm{O}_{3}, \mathrm{In}_{2} \mathrm{O}_{3}, \mathrm{Mn}_{3} \mathrm{O}_{4}, \mathrm{SiO}_{2}\right.$ and $\mathrm{SnO}_{2}$ ) by means of the environmentally relevant organism $P$. subcapitata, using algal growth inhibition assay. In addition, physico-chemical properties of NPs [hydrodynamic size, zeta potential, agglomeration, dissolution and abiotic production of reactive oxygen species (ROS)] were characterized in order to understand their toxic impact. With regard to shed light on the mechanisms behind NP toxicity, the key responses at subcellular level, of the freshwater alga $P$. subcapitata were evaluated as potential markers of cytotoxicity; thus, plasma membrane integrity, intracellular accumulation of ROS, metabolic activity and photosynthetic performance was assessed in algal cells chronic exposed $(72 \mathrm{~h})$ to different NP concentrations. To our knowledge, this is the first work that provides a comprehensive study of the impact of $\mathrm{Al}_{2} \mathrm{O}_{3}, \mathrm{In}_{2} \mathrm{O}_{3}, \mathrm{Mn}_{3} \mathrm{O}_{4}, \mathrm{SiO}_{2}$ and $\mathrm{SnO}_{2} \mathrm{NPs}$ on the physiology of the microalga $P$. subcapitata. This work contributes to the systematic characterization of the potential pollutant hazards of MOx NPs in the aquatic environment.

\section{Material and methods}

\subsection{Preparation of nanoparticles stock suspensions}

The following NPs were used: $\mathrm{Al}_{2} \mathrm{O}_{3}(<50 \mathrm{~nm}), \mathrm{In}_{2} \mathrm{O}_{3}(<100 \mathrm{~nm})$; $\mathrm{Mn}_{3} \mathrm{O}_{4}(<30 \mathrm{~nm}), \mathrm{SiO}_{2}(<20 \mathrm{~nm})$ and $\mathrm{SnO}_{2}(<100 \mathrm{~nm})$, with a purity $\geq 99.1 \%$. All NPs were purchased from Sigma-Aldrich (St. Louis, MO, USA), except for $\mathrm{Mn}_{3} \mathrm{O}_{4}$ NPs, which were obtained from abcr $\mathrm{GmbH}$ (Karlsruhe, Germany).

Stock suspensions of $0.5 \mathrm{~g} \mathrm{~L}^{-1}$ of the different NPs (or $1 \mathrm{~g} \mathrm{~L}^{-1}$ in the case of $\mathrm{In}_{2} \mathrm{O}_{3} \mathrm{NPs}$ ) were prepared in deionized water; subsequently, NPs were shaken, sonicated in a $80-160 \mathrm{~W}$ ultrasonic bath (Bandelin, Sonorex RK 100) for $15 \mathrm{~min}$ and sterilized under an ultraviolet light $(253.7 \mathrm{~nm}$ ), using a Toshiba $15 \mathrm{~W}$ lamp (Ref: Toshiba GL 15), for $30 \mathrm{~min}$. The stock suspensions of NPs were stored up to one month, at $4{ }^{\circ} \mathrm{C}$, in the dark. Before each experiment, the suspensions were shaken and sonicated for $15 \mathrm{~min}$.

\subsection{Characterization of NPs in aqueous suspension}

The characterization of the NPs was performed in OECD algal medium or in water in the absence of algal cells, under the same conditions of the assays with algae (as described below; Section 2.4).

The hydrodynamic size was evaluated by dynamic light scattering (DLS) using a polystyrene cuvette (DTS0012) and zeta potential was evaluated using a folded capillarity cell (DTS1070), at $25^{\circ} \mathrm{C}$, in a Zetasizer Nano ZS (Malvern Instruments, UK) with Zetasizer software (version 7.11). For this purpose, the NPs were suspended at a concentration corresponding to $72 \mathrm{~h}-\mathrm{EC}_{50}$ values (see Section 2.4); $\mathrm{In}_{2} \mathrm{O}_{3}$ NPs were suspended at $100 \mathrm{mg} \mathrm{L}^{-1}$.

The stability of the NPs was studied by measuring the metal(loid)s dissolved from the NPs. Thus, the NPs were suspended in water or OECD medium at a concentration corresponding to $72 \mathrm{~h}-\mathrm{EC}_{50}$ values (see Section 2.4) or at $100 \mathrm{mg} \mathrm{L}^{-1}$. After $72 \mathrm{~h}$ of incubation, samples were taken, centrifuged at $20,000 \mathrm{xg}$ for $30 \mathrm{~min}$ at $25^{\circ} \mathrm{C}$ and the supernatants carefully removed. The metal(loid)s were quantified by atomic absorption spectroscopy with flame atomization (AAS-FA) (Mn), with electrothermal atomization (AAS-EA) (Al, In and Sn) or by inductively coupled plasma - optical emission spectrometry (ICP-OES) (Si) in an Analytik Jena novAA 350, a Perkin Elmer AAnalyst 600 spectrometer or a Thermo Fisher iCAP 7000 series spectrometer, respectively. The total concentration of Al, In, Mn or Sn present in the NPs was evaluated after total digestion of the NPs with aqua regia. For this purpose, $2.0 \mathrm{~mL}$ of NP suspensions were placed in contact with $4.0 \mathrm{~mL}$ of aqua regia $\left(1.0 \mathrm{~mL}\right.$ nitric acid $\left[13.4 \mathrm{~mol} \mathrm{~L}^{-1}\right]$ and $3.0 \mathrm{~mL}$ hydrochloric acid [12.2 $\left.\mathrm{mol} \mathrm{L}^{-1}\right]$ ) for $1 \mathrm{~h}$; subsequently, samples were filtered through a 0.45 - $\mu \mathrm{m}$-pore-size membrane and quantitatively transferred to $10 \mathrm{~mL}$ volumetric flasks, appropriately diluted and metal content determined by AAS-FA.

NP agglomeration was evaluated through a sedimentation assay, as previously described (Sousa et al., 2018). With this aim, NPs were suspended in OECD medium at $100 \mathrm{mg} \mathrm{L}^{-1}$ and agitated at $150 \mathrm{rpm}$ for $72 \mathrm{~h}$, at $25^{\circ} \mathrm{C}$. For a given incubation time, samples were withdrawn and placed in $3 \mathrm{~mL}$ cuvettes. The turbidity change of the samples was monitored, spectrophotometrically (optical density at $600 \mathrm{~nm}, \mathrm{OD}_{600}$ ) over a period of $60 \mathrm{~min}$. The percentage of initial $\mathrm{OD}_{600}$ after $60 \mathrm{~min}$ was calculated according to Eq. (1):

$\%$ of initial $\mathrm{OD}_{600}$ after $60 \mathrm{~min}=\left(\mathrm{OD}_{t} / \mathrm{OD}_{i}\right) \times 100$

where $\mathrm{OD}_{t}$ is the $\mathrm{OD}_{600}$ after $60 \mathrm{~min}$ of settling and $\mathrm{OD}_{i}$ is the $\mathrm{OD}_{600}$ at zero time. The $\%$ of initial $\mathrm{OD}_{600}$ after $60 \mathrm{~min}$ calculated was plotted against the incubation time of NPs.

\subsection{Strain, medium and culture conditions}

In this study, the freshwater green alga Pseudokirchneriella subcapitata (strain 278/4) was used. The alga was obtained from the Culture Collection of Algae and Protozoa (CCAP), UK, and maintained in OECD agar medium (OECD, 2011).

The pre-cultures were prepared, weekly, by inoculating $40 \mathrm{~mL}$ of OECD medium, in $100 \mathrm{~mL}$ Erlenmeyer flasks, with a loop of algae. Cells were incubated for 3 days, at $25^{\circ} \mathrm{C}$, in an orbital shaker at $100 \mathrm{rpm}$, under continuous "natural white" light-emitting diodes (LEDs) with a colour temperature of $4000-4200 \mathrm{~K}$ and an intensity of $4000 \mathrm{~lx}$ at the surface of the flasks.

The cultures were obtained by inoculating the algal cells, from the pre-cultures, at $5 \times 10^{4}$ cells $\mathrm{mL}^{-1}$ in $100 \mathrm{~mL}$ of OECD medium, in $250 \mathrm{~mL}$ Erlenmeyer flasks; algal cells were incubated for $48 \mathrm{~h}$ under the same conditions described for the pre-cultures. After growth, algal cells were harvested by centrifugation $(2,500 \times g$ for $5 \mathrm{~min})$ and suspended in deionized water.

\subsection{Algal bioassays}

Concentration-response curves of $\mathrm{Al}_{2} \mathrm{O}_{3}, \mathrm{In}_{2} \mathrm{O}_{3}, \mathrm{Mn}_{3} \mathrm{O}_{4}, \mathrm{SiO}_{2}$ or $\mathrm{SnO}_{2} \mathrm{NPs}$ were performed using the freshwater alga growth inhibition test (OECD, 2011). The toxicity caused by the respective metal ions (in the case of $\mathrm{Al}_{2} \mathrm{O}_{3}, \mathrm{In}_{2} \mathrm{O}_{3}, \mathrm{Mn}_{3} \mathrm{O}_{4}$ and $\mathrm{SnO}_{2} \mathrm{NPs}$ ) was compared. Similar experiences with $\mathrm{Si}$ (a metalloid) could not be done since the chemical behaviour of this element is different from the metals (Hirner and Flaßbeck, 2005); the dissolution of $\mathrm{SiO}_{2}$ in water, originates as the formation of orthosilicic acid (Iler, 1978). Algal cells in exponential phase of growth ( 2 days), at $5 \times 10^{4}$ cells $\mathrm{mL}^{-1}$, were exposed (at least) to seven concentrations of toxicants, arranged in a geometric series, in OECD medium. The assays were conducted in $250 \mathrm{~mL}$ Erlenmeyer flasks, at a final volume of $100 \mathrm{~mL}$. As control, algal cells were grown in the absence of toxicant. The metals stock solutions used were: $\mathrm{Al}\left(\mathrm{NO}_{3}\right)_{3}$ (1000 $\mathrm{m} \mathrm{L}^{-1}$, Merck, Darmstadt, Germany), In $\left(\mathrm{NO}_{3}\right)_{3}\left(1000 \mathrm{mg} \mathrm{L}^{-1}\right.$, Sigma-Aldrich), $\mathrm{MnCl}_{2}\left(2000 \mathrm{mg} \mathrm{L}^{-1}\right.$, Merck) and $\mathrm{SnCl}_{4}\left(1000 \mathrm{mg} \mathrm{L}^{-1}\right.$, Merck). After $72 \mathrm{~h}$ of incubation, under the conditions described above, algal cell concentrations were determined using an automated cell counter (TC10, Bio-Rad), image analysis-based. The test endpoint was biomass yield, defined as biomass (number of cells $\mathrm{mL}^{-1}$ ) at the end of the exposure period $(72 \mathrm{~h})$ minus the biomass at the start of the exposure period (OECD, 2011). The $72 \mathrm{~h}-\mathrm{EC}_{10}, \mathrm{EC}_{25}, \mathrm{EC}_{50}, \mathrm{EC}_{75}$ and $\mathrm{EC}_{90}$ 
values, which represent the toxicant concentration that induces an inhibition of $10,25,50,75$ or $90 \%$, respectively, of algal growth after $72 \mathrm{~h}$, when compared with control, were determined using a linear interpolation method (TOXCALC version 5.0.32, Tidepool Scientific Software, McKinleyville, CA, USA).

$P$. subcapitata algal cells were also exposed to three concentrations (corresponding to the previously calculated $72 \mathrm{~h}-\mathrm{EC}_{10}, 72 \mathrm{~h}-\mathrm{EC}_{50}$, and $72 \mathrm{~h}-\mathrm{EC}_{90}$ values) of each nanoparticle for $72 \mathrm{~h}$. For concentration-response curve determination, the assays were carried out as described above. After exposure to NPs, algal cells were centrifuged at 2,500 x $g$ for $5 \mathrm{~min}$ and, subsequently re-suspended in fresh OECD medium at a final concentration of $3 \times 10^{6}$ cells $\mathrm{mL}^{-1}$ (for photosynthetic perfor-

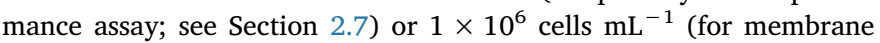

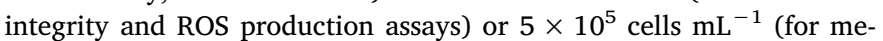
tabolic activity). The use of different cell concentrations was a consequence of the optimization of conditions, previously performed for each determination. The specific works on which the conditions were originally described can be found below (Sections 2.6 and 2.7).

\subsection{The entrapment assay of algae}

The dispersibility of NP-alga hetero-agglomerates was evaluated using an algal entrapment-test. A known concentration of algal cells $\left(1 \times 10^{5}\right.$ or $3 \times 10^{6}$ cells $\mathrm{mL}^{-1}$, which corresponded to the minimal and maximal cell concentrations achieved at the end of $\mathrm{EC}_{10}$ and $\mathrm{EC}_{90}$ assays, respectively) was incubated, in the same conditions of algal bioassays, with the highest NP concentration tested; for these NP concentrations, no algal growth was observed. After $72 \mathrm{~h}$ of incubation, the algal-NP suspensions were vortexed and dispersed cell concentrations were determined using an automated cell counter. The reduction of algal cells in suspension (in percentage), which corresponded to the algae entrapped in the NP agglomerates, was determined considering the initial algal cell concentration as reference.

\subsection{Staining procedures}

SYTOX Green (SG) staining was used to evaluate the impact of NPs on plasma membrane integrity of algal cells (Machado and Soares, 2012). For this purpose, algal cells were exposed to NPs, at a concentration which corresponded to the $72 \mathrm{~h}-\mathrm{EC}_{90}$ value (for each $\mathrm{NP}$ ), for

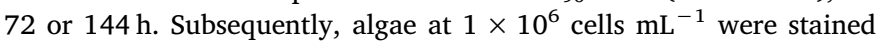
with $0.5 \mu \mathrm{mol} \mathrm{L}^{-1} \mathrm{SG}$ (Molecular Probes, Invitrogen), for $20 \mathrm{~min}$ in the dark at $25^{\circ} \mathrm{C}$. As positive control (cells with disrupted plasma membrane; SG positive cells), algae were heat-treated $\left(65^{\circ} \mathrm{C}, 60 \mathrm{~min}\right)$ in a water bath and subsequently stained with SG. Cells were observed in a Leica DLMB epifluorescence microscope (Wetzlar GmbH, Germany), equipped with an HBO-100 mercury lamp and the GFP filter set from Leica. For each experiment and condition tested, two samples of $\sim 200$ cells were analysed in randomly selected microscope fields.

The metabolic activity of algal cells was evaluated using fluorescein diacetate (FDA). After treatment with NPs, $5 \times 10^{5}$ cells $\mathrm{mL}^{-1}$ in OECD medium were stained with $20 \mu \mathrm{mol} \mathrm{L}^{-1}$ FDA for $40 \mathrm{~min}$ in the dark at $25^{\circ} \mathrm{C}$, as previously described (Machado and Soares, 2013). The assays were carried out in quintuplicate in 96-well flat microplates (Orange Scientific). Fluorescence intensity (in relative fluorescent units, RFUs) was measured in a microplate reader at a fluorescence excitation wavelength of $485 / 14 \mathrm{~nm}$ and an emission wavelength of 535/25 nm. Fluorescence was corrected by subtracting cell, culture medium and dye autofluorescence. The results were expressed as the ratio of fluorescence in the cells exposed to MOx NPs/fluorescence in the control (nontreated cells).

The intracellular accumulation of ROS was quantitatively assessed using the fluorescent probe $2^{\prime}, 7^{\prime}$-dichlorodihydrofluorescein diacetate ( $\mathrm{H}_{2}$ DCFDA; Sigma-Aldrich) (Machado and Soares, 2016). Control and cells treated with NPs, at $1 \times 10^{6}$ cells $\mathrm{mL}^{-1}$, were mixed with $10 \mu \mathrm{mol}$ $\mathrm{L}^{-1} \mathrm{H}_{2}$ DCFDA, dispensed in quintuplicate in a 96-well microplate and incubated in the dark for $90 \mathrm{~min}$ at $25^{\circ} \mathrm{C}$. Fluorescence was measured and corrected and the results expressed as described above for metabolic activity.

The production of ROS by NPs in abiotic conditions (in the absence of cells) was also quantified by deacetylation of the probe $\mathrm{H}_{2}$ DCFDA to $\mathrm{H}_{2} \mathrm{DCF}$, as previously described (Aruoja et al., 2015). NPs (at a concentration corresponding to the respective $72 \mathrm{~h}$-EC 90 value) were incubated for $72 \mathrm{~h}$ in OECD medium in the same conditions described above for the assays with algal cells. Then, $100 \mu \mathrm{L}$ of samples were collected and incubated with $100 \mu \mathrm{L}$ of $52 \mu \mathrm{mol} \mathrm{L}^{-1} \mathrm{H}_{2} \mathrm{DCF}$, placed in quintuplicate in a 96-well microplate and incubated in the dark for $45 \mathrm{~min}$ at $25^{\circ} \mathrm{C}$. A blank and a positive control were prepared by replacing the sample by equal volume of OECD medium or $52 \mu \mathrm{mol} \mathrm{L}{ }^{-1}$ $\mathrm{H}_{2} \mathrm{O}_{2}$, respectively, as previously described (Sousa et al., 2018). Fluorescence was measured and corrected as described above for metabolic activity. The results were presented as the ratio of fluorescence of the assay/fluorescence of the blank.

\subsection{Algal photosynthetic performance determination}

Photosynthetic performance of Photosystem II (PSII) of algal cells was evaluated trough the determination of the effective photochemical quantum yield of PS II ( $\Phi_{\text {PSII }}$ ) by pulse amplitude modulated (PAM) fluorescence assay, using a chlorophyll fluorometer (Walz, JUNIORPAM), as previously described (Sousa et al., 2018). Algal cells not exposed (control) or exposed to NPs were suspended in OECD medium at $3 \times 10^{6} \mathrm{~mL}^{-1}$. After a dark adaptation for $30 \mathrm{~min}$ the minimal fluorescence was measured. Then, the maximum fluorescence was determined by exposing the cells for $600 \mathrm{~ms}$ to a blue LED saturation pulse of $10,000 \mu \mathrm{mol} \mathrm{m}^{-2} \mathrm{~s}^{-1}$ light intensity and a measuring beam of $5 \mathrm{~Hz}$. $\Phi_{\text {PSII }}$ was automatically calculated using the WinControl software (version 3.25), according to Eq. (2) (Genty et al., 1989):

$\Phi_{\mathrm{PSII}}=\left(F_{m}^{\prime}-F\right) / F_{m}^{\prime}$

where $F_{m}^{\prime}$ is the maximal fluorescence level (when PSII reaction centres are closed by a strong light pulse) and $F^{\prime}$ is the fluorescence level shortly before a strong light pulse.

The results were expressed as a ratio of the values in assay (cells treated with the MOx NPs) and the values in control.

\subsection{Microphotographs}

Nanoparticle suspensions were observed by phase-contrast microscopy. Algal cells in the presence of NPs were also microscopically observed by phase-contrast and fluorescence microscopy using an I3 filter set from Leica. All images were acquired with a Leica DC $300 \mathrm{~F}$ camera, using a N plan $\times 100$ objective, and were processed using Leica IM 50-Image manager software.

\subsection{Reproducibility of the results and statistical analysis}

The hydrodynamic size and zeta potential measurements were performed one time in duplicate; in each measurement, ten repetitions were considered. The other studies were repeated at least three times in duplicate $(n \geq 6)$. The data are presented as mean values \pm standard deviations (SD). The mean values were subjected to one-way ANOVA, followed by Tukey-Kramer multiple comparison method; $P$ values $<$ 0.05 were considered statistically significant.

\section{Results}

\subsection{Physico-chemical characterization of NP suspensions}

The NP suspensions were characterized in the algal (OECD) medium; for comparative purposes, the same analysis was performed in 
A

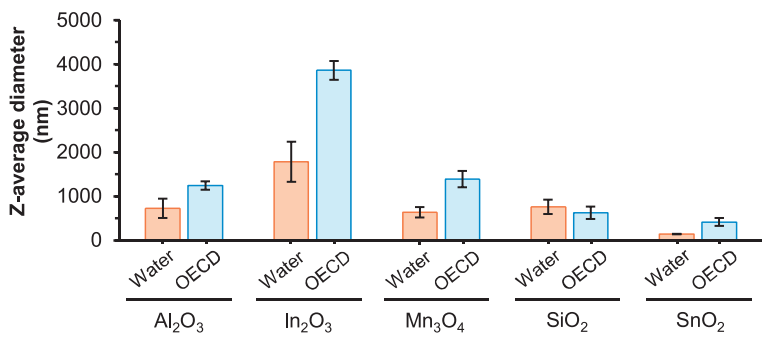

B

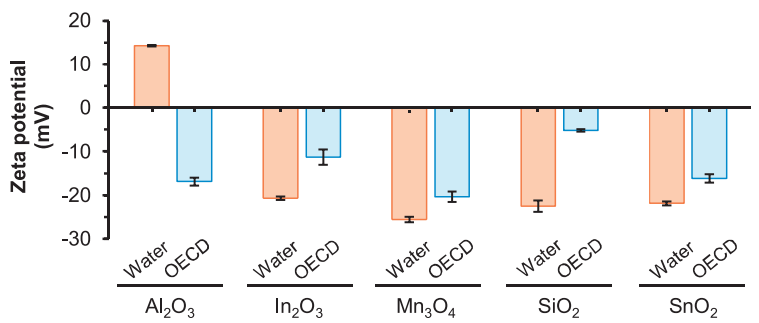

C

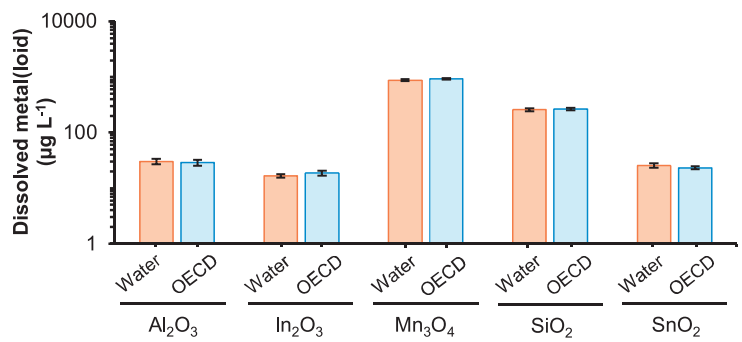

Fig. 1. Physicochemical characterization of the nanoparticles in water and in OECD medium. NPs were suspended in water or OECD medium, at $72 \mathrm{~h}-\mathrm{EC}_{50}$ values, except for $\mathrm{In}_{2} \mathrm{O}_{3} \mathrm{NPs}$, which were suspended at $100 \mathrm{mg} \mathrm{L}^{-1}$. A and B - Zaverage diameter and zeta potential, respectively, at $0 \mathrm{~h}$ (immediately after suspension of the NPs). C - Dissolved metal(loid)s from the NPs at $72 \mathrm{~h}$. The data represent the mean values; standard deviations are presented as vertical error bars. The hydrodynamic size and zeta potential measurements were performed one time in duplicate; in each measurement, ten repetitions were considered. NP solubility experiments were carried out at least three times in duplicate $(n \geq 6)$.

deionized water.

The hydrodynamic (Z-average) diameter of the NPs in suspension as well as the zeta potential was determined after the preparation of the suspensions $(0 \mathrm{~h})$. Z-average diameter of the NPs, in OECD medium, ranged between 418 and $3859 \mathrm{~nm}$ while in water it ranged between 145 and $1785 \mathrm{~nm}$ (Fig. 1A). Since all NPs, when in powder, had a nominal size of $<100 \mathrm{~nm}$, these results showed that the NPs agglomerated almost instantaneously after suspension in aqueous solution. The agglomeration of all NPs studied, increased over the time, in OECD medium, as can be seen from the sedimentation profiles of the NPs (Fig. S1). The microscopic observation of NPs suspensions, after $72 \mathrm{~h}$ of incubation, confirmed the formation of agglomerates in all NPs studied (Fig. S2). This effect was particularly evident for $\mathrm{Mn}_{3} \mathrm{O}_{4}$ and $\mathrm{In}_{2} \mathrm{O}_{3} \mathrm{NPs}$, where agglomerates could be detected with the naked eye (Fig. S3).

The zeta potential of NPs, in both media, had negative values (between -5 and $-25 \mathrm{mV}$ ), except for $\mathrm{Al}_{2} \mathrm{O}_{3}$ NPs in water, which presented a value of $+14 \mathrm{mV}$ (Fig. 1B). In a general way, the magnitude of the zeta potential values was lower in OECD medium comparatively to water (Fig. 1B).

The solubility of all NPs, after $72 \mathrm{~h}$ of incubation, at a concentration corresponding to $72 \mathrm{~h}-\mathrm{EC}_{50}$ values, was similar in OECD medium and deionized water (Fig. 1C). For comparative purposes, the NPs were suspended in OECD medium at $100 \mathrm{mg} \mathrm{L}^{-1}$. $\mathrm{Mn}_{3} \mathrm{O}_{4}$ NPs were the most soluble; for these NPs, after $72 \mathrm{~h}$ of incubation, the amount of Mn ions released was $1000 \mu \mathrm{L} \mathrm{L}^{-1}$ (Fig. S4), which corresponded to a NP solubilisation of $4.2 \%$. The Si released from NPs was $452 \mu \mathrm{g} \mathrm{L}^{-1}$ (Fig. S4), which corresponded to a NPs solubilisation of $\sim 1 \%$. The other NPs studied displayed a much lower solubility $(\leq 0.15 \%)$.

The suspension of NPs in OECD medium did not modify substantially the $\mathrm{pH}$, in the presence or absence of algae, during the incubation period of $72 \mathrm{~h}$ (Table S2).

\subsection{Hazard ranking of NPs}

In the last decade, there has been a rapid advance of nanotechnology in terms of developing of new nanomaterials along with their commercial applications, which makes the aspect of nanosafety particularly important. In this context, the potential toxic impact of $\mathrm{Al}_{2} \mathrm{O}_{3}, \mathrm{In}_{2} \mathrm{O}_{3}, \mathrm{Mn}_{3} \mathrm{O}_{4}, \mathrm{SiO}_{2}$ and $\mathrm{SnO}_{2}$ NPs was evaluated using the microalga $P$. subcapitata through the OECD algal growth inhibition test (OECD, 2011). For comparative purposes, the toxicity of the corresponding metal ions was also studied. Hence, $P$. subcapitata cells were exposed to a series of geometric concentrations of the toxicants and the corresponding concentration-response curves (expressed as \% of growth inhibition) were constructed (Fig. 2). Among the NPs studied, $\mathrm{SnO}_{2}$ was the most toxic with a $72 \mathrm{~h}-\mathrm{EC}_{50}$ value of $2.1 \mathrm{mg} \mathrm{L}^{-1}$ (Table S3). Considering the $72 \mathrm{~h}-\mathrm{EC}_{50}$ values (Table S3), the decreasing order of toxicity of the NPs studied is: $\mathrm{SnO}_{2}>\mathrm{Al}_{2} \mathrm{O}_{3}>\mathrm{Mn}_{3} \mathrm{O}_{4}>\mathrm{SiO}_{2}>\mathrm{In}_{2} \mathrm{O}_{3}$. Related to the metal ions present in the NPs, the decreasing order of toxicity is: $\mathrm{Sn}^{4+}>\mathrm{In}^{3+}>\mathrm{Al}^{3+}>\mathrm{Mn}^{2+}$ (Table S3). A detailed comparison of the NPs hazards, considering the respective $72 \mathrm{~h}-\mathrm{EC}_{10}, \mathrm{EC}_{25}$, $\mathrm{EC}_{50}, \mathrm{EC}_{75}$ and $\mathrm{EC}_{90}$ values is presented in the table S3.
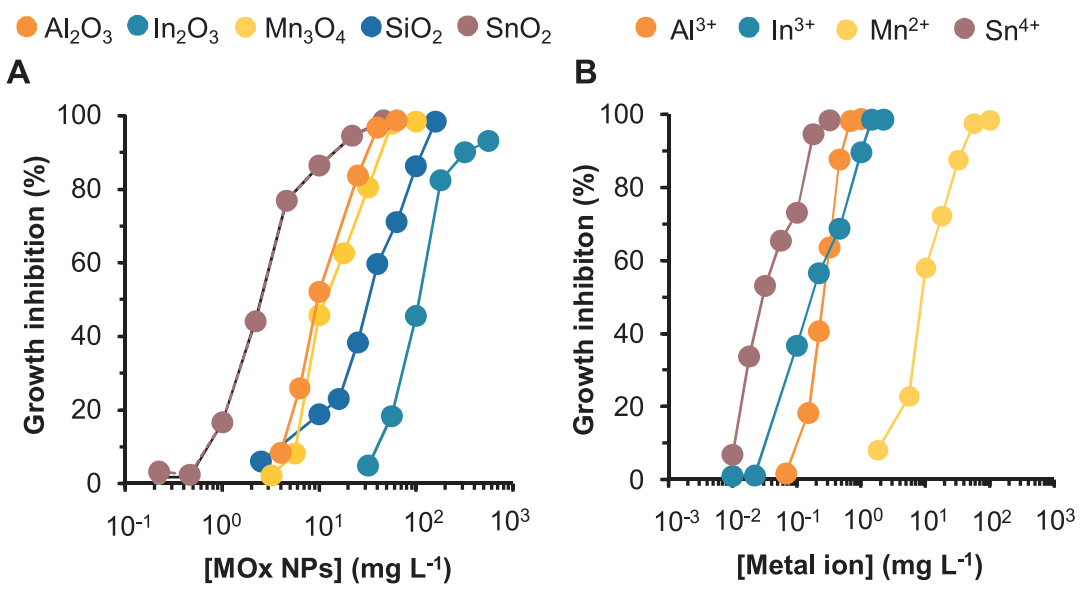

Fig. 2. Concentration-response curves of the nanoparticles or the respective metal ions. A and B - Algal cells of $P$. subcapitata exposed to NPs or to metal ions, respectively, in OECD medium, for $72 \mathrm{~h}$. The data are presented as mean values from at least three independent experiments performed in duplicate $(n \geq 6)$; standard deviations are presented (vertical error bars). 
A
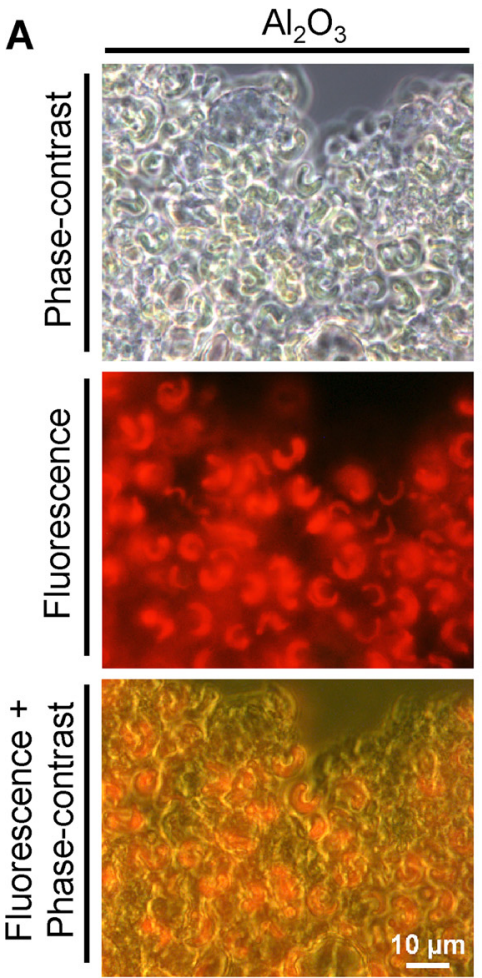
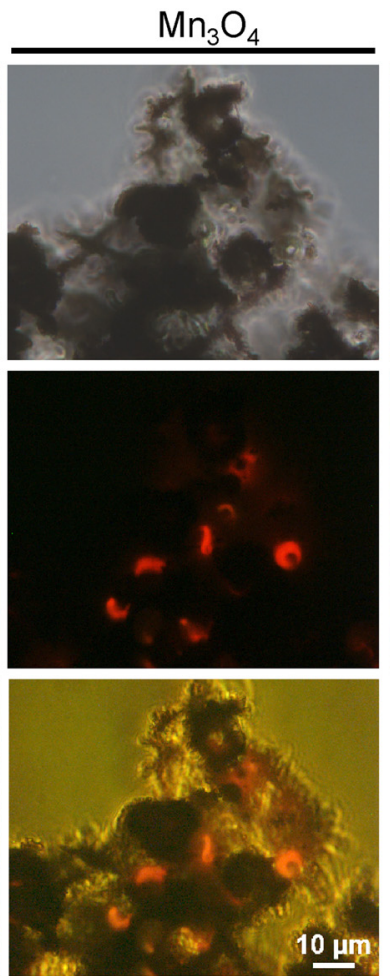
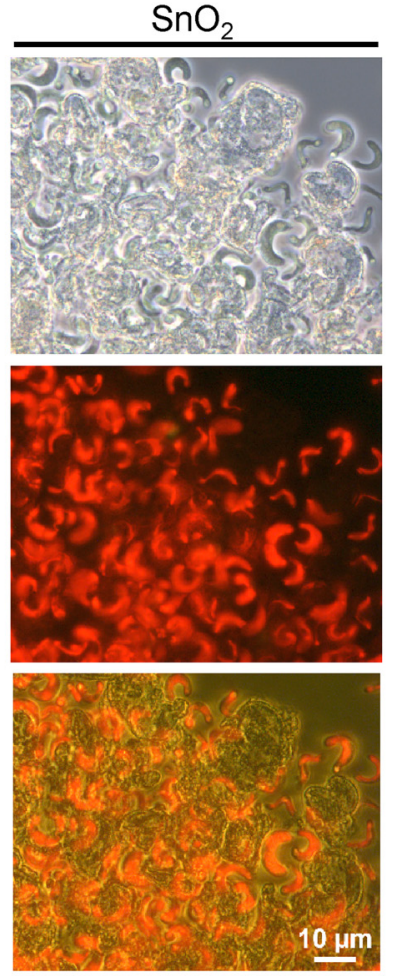

Fig. 3. Possible toxic mechanisms of the nanoparticles. A - Microscopic visualization of algal-NP agglomerates. Algal cells were incubated with NPs for $72 \mathrm{~h}$, at a concentration corresponding to $72 \mathrm{~h}-\mathrm{EC}_{90}$ values. B Evaluation of abiotic ROS production by nanoparticles. NPs were suspended in OECD medium at a concentration corresponding to $72 \mathrm{~h}-\mathrm{EC}_{50}$ values and incubated for $72 \mathrm{~h}$ in the same conditions of the biotic assays. Blank and positive control were prepared by incubating the $\mathrm{H}_{2} \mathrm{DCF}$ probe with OECD medium or $26 \mu \mathrm{mol} \mathrm{L}{ }^{-1} \mathrm{H}_{2} \mathrm{O}_{2}$, respectively. The data represent the mean values from at least three independent experiments performed in duplicate $(n \geq 6)$; standard deviations are presented (vertical error bars). The mean values were subjected to one way ANOVA, followed by Tukey-Kramer multiple comparison method; the result with asterisk is significantly different $(P<0.05)$. C- Theoretical algal growth inhibition. Growth inhibition was calculated considering the metal ions released from NPs, at a concentration corresponding to $72 \mathrm{~h}-\mathrm{EC}_{50}$ values, and concentration-response curves of the metals (Fig. 2B).

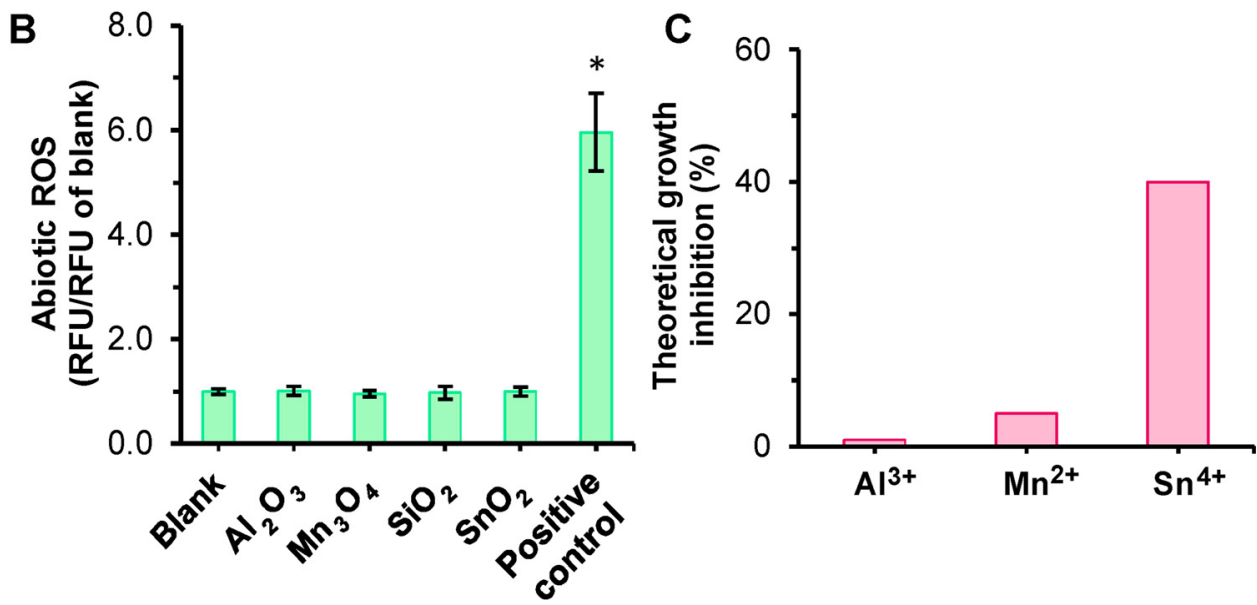

\subsection{How can NPs affect algal growth?}

Algal cells can be sequestered due to their co-agglomeration with NPs; in this situation, the access of algae to nutrients, present in the culture medium, can be reduced or impaired. The co-agglomeration of NPs and algal cells was observed for $\mathrm{Al}_{2} \mathrm{O}_{3}, \mathrm{Mn}_{3} \mathrm{O}_{4}$ and $\mathrm{SnO}_{2}$ NPs; this effect was particularly notorious at high NPs concentrations (corresponding to $72 \mathrm{~h}-\mathrm{EC}_{90}$ values). These hetero-agglomerates presented a loose structure appearance (Fig. 3A) and were easily dispersed by simple vortexing of the suspensions. After the stirring of these heteroagglomerates the proportion of algal cells entrapped in these structures could be estimated. It was $<7 \%$ (Table S4). In these algal-NPs agglomerates, it was possible to observe cells inside and at the periphery of the structures as well as in the surrounding medium. For $\mathrm{SiO}_{2}$ and $\mathrm{In}_{2} \mathrm{O}_{3}$, only NP homoagglomerates were observed. Together, these observations strongly indicated that the toxicity caused by NPs cannot be attributed to nutritional limitation of algae due to their entrapment by the NPs.

The potential of NPs to generate reactive oxygen species (ROS) and, thus, to induce oxidative stress (OS) and cell toxicity was assessed using the general redox probe $\mathrm{H}_{2}$ DCFDA (Tarpey et al., 2004), previously deacetylated to $\mathrm{H}_{2} \mathrm{DCF}$. Under the concentrations and conditions used, the NPs studied did not generate abiotic ROS (Fig. 3B). Due to the absence of a pro-oxidant effect, it is not plausible that the toxicity observed could be attributed to the abiotic induction of OS, by the NPs, in the surrounding medium.

A common question in nanotoxicology is: what is the contribution of the metal leached from the NPs to the observed toxicity? To answer this question, the theoretical algal growth inhibition was calculated (Fig. 3C), in percentage, taking into account the amount of metals released from the NPs, at a concentration corresponding to $72 \mathrm{~h}-\mathrm{EC}_{50}$ values (Fig. 1C), and the concentration-response curves of metals ions (Fig. 2B). The comparative analysis of the observed ( $\sim 50 \%$ of algal growth inhibition) with the expected toxicity (considering the metals released from the NPs) revealed that, in the case of $\mathrm{Al}_{2} \mathrm{O}_{3}$, the toxicity can be attributed to the NPs, since the toxicity that can be attributed to the metals released should be $<1 \%$ (Fig. $3 \mathrm{C}$ ). For $\mathrm{Mn}_{3} \mathrm{O}_{4}$, the toxicity could be mainly attributed to the NPs, although a small inhibition $(<5 \%)$ could be due to the release of Mn ions. On the contrary, the toxicity of $\mathrm{SnO}_{2} \mathrm{NPs}$ can be attributed mainly to the release of $\mathrm{Sn}$ ions, 
as the Sn dissolved from the NPs should provoke an algal growth inhibition of $40 \%$ (Fig. 3C).

\subsection{NP toxicity: cellular targets}

To further contribute for the elucidation of the modes of toxicity of the NPs, different key cell targets were assessed: cell membrane integrity, metabolic activity, intracellular accumulation of ROS and photosynthetic activity. Therefore, algal cells were exposed for $72 \mathrm{~h}$ to different concentrations of NPs, corresponding to $72 \mathrm{~h}-\mathrm{EC}_{10}, \mathrm{EC}_{50}$ and $\mathrm{EC}_{90}$ values. With this strategy, algal cells were chronically exposed to a wide range of NP concentrations: from a concentration with a little impact on algal growth ( $72 \mathrm{~h}-\mathrm{EC}_{10}$ values) to a concentration where the growth was practically arrested ( $72 \mathrm{~h}-\mathrm{EC}_{90}$ values). This study was not conduced with $\operatorname{In}_{2} \mathrm{O}_{3}$, since these NPs presented a lower toxicity: a $72 \mathrm{~h}$ $\mathrm{EC}_{50}$ value $>100 \mathrm{mg} \mathrm{L}^{-1}$ (Table S3).

\subsubsection{Cell membrane integrity}

Cell membrane integrity was evaluated using the fluorescent probe SG. Cells with an intact membrane are not penetrated by SG (SG negative cells) (Machado and Soares, 2012). The exposure of algal cells to the highest NP concentration tested (which corresponded to $72 \mathrm{~h}-\mathrm{EC}_{90}$ value, for each NP), induced growth arrest (Fig. 4B) without disruption of cell membrane integrity (Fig. 4A). Extending the exposure of algae to NPs up to $144 \mathrm{~h}$ (6 days), it was possible to observe the growth stop (Fig. 4B), although the cells remained mostly ( $>85 \%$ ) with an intact cell membrane (SG negative cells) (Fig. 4A). These results indicated that these NPs induced an algistatic effect on $P$. subcapitata.

\subsubsection{Metabolic activity}

Metabolic activity of algal cells was assessed through the quantification of the esterase activity, using fluorescein diacetate (FDA) as substrate. Esterases, present in metabolically active cells, hydrolyse the FDA, giving cells with green fluorescence. The decrease of green fluorescence has been used as an indicator of the loss of algal metabolic activity (Dorsey et al., 1989; Machado and Soares, 2013).

Algal cells exposed to $\mathrm{Al}_{2} \mathrm{O}_{3}, \mathrm{Mn}_{3} \mathrm{O}_{4}$ or $\mathrm{SiO}_{2} \mathrm{NPs}$, at concentrations that inhibit 50 or $90 \%$ of algal growth, displayed a reduction of the metabolic activity (Fig. $5 \mathrm{~A}-\mathrm{C}$ ). In the case of $\mathrm{Al}_{2} \mathrm{O}_{3} \mathrm{NPs}$, the reduction of esterase activity was also observed for the lowest concentration tested $\left(4.4 \mathrm{mg} \mathrm{L}^{-1}\right) . \mathrm{SnO}_{2}$ NPs seems not disturb algal metabolic activity, up to $21 \mathrm{mg} \mathrm{L}^{-1}$. In fact, algal cells maintained the esterase activity even when exposed to a concentration that inhibit almost completely cell growth (72 h-EC 90 ) (Fig. 5D).

\subsubsection{Intracellular ROS accumulation}

The accumulation of ROS by algal cells was monitored with the probe $\mathrm{H}_{2}$ DCFDA, which has been used to detect a broad range of ROS (Tarpey et al., 2004). Algal cells exposed to $\mathrm{Al}_{2} \mathrm{O}_{3}, \mathrm{Mn}_{3} \mathrm{O}_{4}$ or $\mathrm{SiO}_{2} \mathrm{NPs}$ accumulated ROS (Fig. 6). Since these NPs did not generate ROS in abiotic conditions (Fig. 3B), the levels of ROS exhibited by algal cells were, most likely, intracellularly generated. The oxidative stress experienced by algae was particularly notorious in cells exposed to high $\mathrm{Al}_{2} \mathrm{O}_{3}$ and $\mathrm{Mn}_{3} \mathrm{O}_{4}$ NP concentrations (corresponding to $72 \mathrm{~h}-\mathrm{EC}_{90}$ values) (Fig. 6). Within the NPs studied, the decreasing order of intracellular ROS accumulation was: $\mathrm{Mn}_{3} \mathrm{O}_{4}>\mathrm{Al}_{2} \mathrm{O}_{3}>\mathrm{SiO}_{2} . \mathrm{SnO}_{2} \mathrm{NPs}$, up to $21 \mathrm{mg} \mathrm{L}^{-1}$, did not induce intracellular ROS accumulation (Fig. 6).

\subsubsection{Photosynthetic performance}

The photosynthetic performance was evaluated using a PAM fluorescence assay. It was possible to observe that algal cells exposed to $\mathrm{Al}_{2} \mathrm{O}_{3}, \mathrm{Mn}_{3} \mathrm{O}_{4}, \mathrm{SiO}_{2}$ or $\mathrm{SnO}_{2} \mathrm{NPs}$ presented a reduction in the light utilization efficiency of PSII (reduction of photosynthetic efficiency). The decrease of $\Phi_{\text {PSII }}$ was particularly noticeable in algal cells exposed to high NPs concentrations (Fig. 7). The reduction of $\Phi_{\mathrm{PSII}}$ is generally seen as a sensitive indicator of stress (Juneau and Popovic, 1999).

\section{Discussion}

The physicochemical characterization of NPs in aqueous suspension, namely the study of their agglomeration and the stability (solubilisation), is essential to understand their possible toxic effects (Rogers et al., 2010; Wang et al., 2017). The evaluation of the electrokinetic potential of $\mathrm{Al}_{2} \mathrm{O}_{3}, \mathrm{In}_{2} \mathrm{O}_{3}, \mathrm{Mn}_{3} \mathrm{O}_{4}, \mathrm{SiO}_{2}$ and $\mathrm{SnO}_{2}$, in OECD algal medium and deionized water, showed that these NPs presented low zeta potential values in aqueous media (Fig. 1B). These results indicated that these NPs are poorly stabilized as consequence of the low electrostatic repulsion between adjacent particles. Particles with low zeta potential tend to agglomerate (Hanaor et al., 2012). Consistent with these data, it was observed that the NPs studied in aqueous media presented a hydrodynamic size between $\sim 150-3900 \mathrm{~nm}$ (Fig. 1A). In addition, the sedimentability of the NPs increased over the time (Fig. $\mathrm{S} 1$ ), and it was possible to detect NP agglomerates by optical microscopy (Fig. S2) or even with the naked eye $\left(\mathrm{In}_{2} \mathrm{O}_{3}\right.$ and $\left.\mathrm{Mn}_{3} \mathrm{O}_{4}\right)$ (Fig. S3). In line with our data, zeta potential values of the same order of magnitude were described for $\operatorname{In}_{2} \mathrm{O}_{3}$ (Ahamed et al., 2017; Hasegawa et al., 2012; Jeong et al., 2016), $\mathrm{Mn}_{3} \mathrm{O}_{4}$ and $\mathrm{SiO}_{2}$ NPs (Aruoja et al., 2015). Similarly, the agglomeration of the NPs was observed by other authors. For $\mathrm{Al}_{2} \mathrm{O}_{3}$ NPs, a hydrodynamic size between 392 and $1232 \mathrm{~nm}$ in OECD medium was described (Aruoja et al., 2015; Sadiq et al., 2011). In the case of $\mathrm{Mn}_{3} \mathrm{O}_{4}$ and $\mathrm{SiO}_{2}$ NPs, Aruoja et al. (2015) described an hydrodynamic size in water of 395 and $148 \mathrm{~nm}$, respectively, and in OECD medium of 920 and $154 \mathrm{~nm}$, respectively.

NPs can exert a toxic impact on algae by different ways such as sequestration of the cells by the NPs (isolating the cells from nutrients), generation of ROS in the external milieu or through the release of metal (loid)s (NPs dissolution) (Aruoja et al., 2015; Rogers et al., 2010; Wang
A

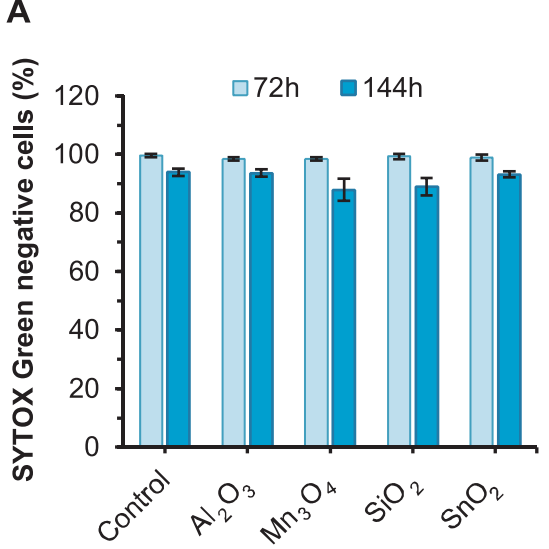

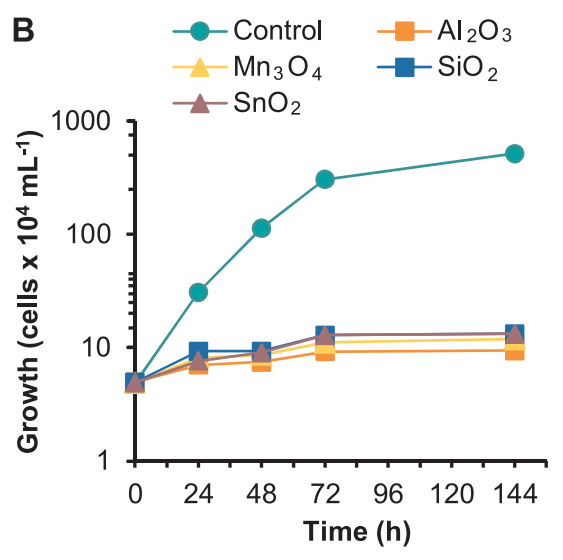

Fig. 4. Effect of nanoparticles on cell membrane integrity and growth of $P$. subcapitata. Algal cells were incubated in OECD medium in the absence (control) or in the presence of NPs, at a concentration corresponding to $72 \mathrm{~h}-\mathrm{EC}_{90}$ values. A - Cell membrane integrity, evaluated by SYTOX Green exclusion assay, after the exposure of algal cells to NPs for $72 \mathrm{~h}$ or $144 \mathrm{~h}$. B - Algal growth. The data are presented as mean values from at least three independent experiments performed in duplicate $(n \geq 6)$; standard deviations are presented (vertical error bars). A - Means for $72 \mathrm{~h}$ or $144 \mathrm{~h}$ are not significantly different $(P<0.05 ;$ ANOVA $)$. 
A

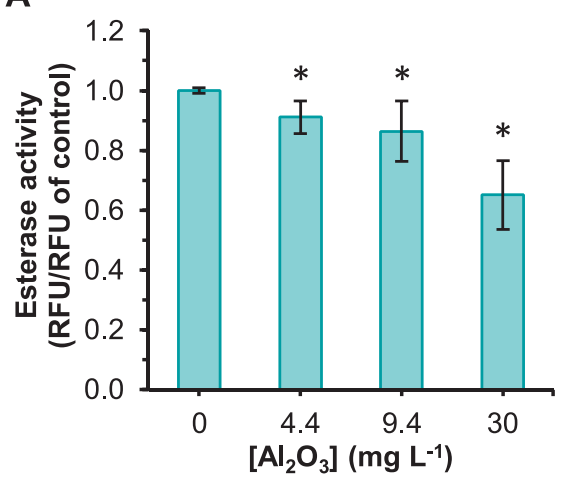

C

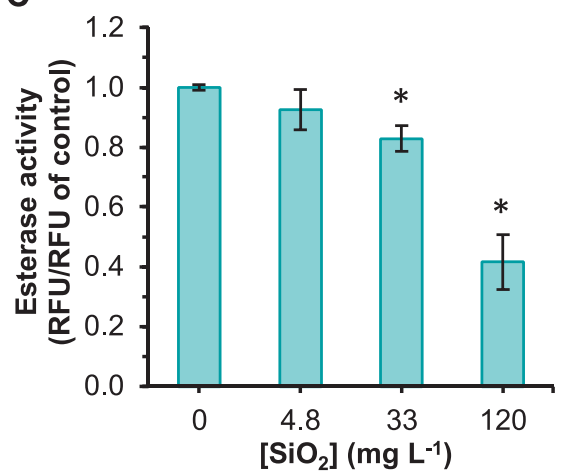

A

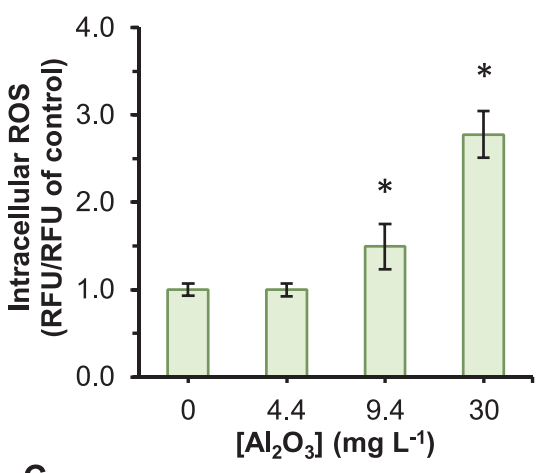

C

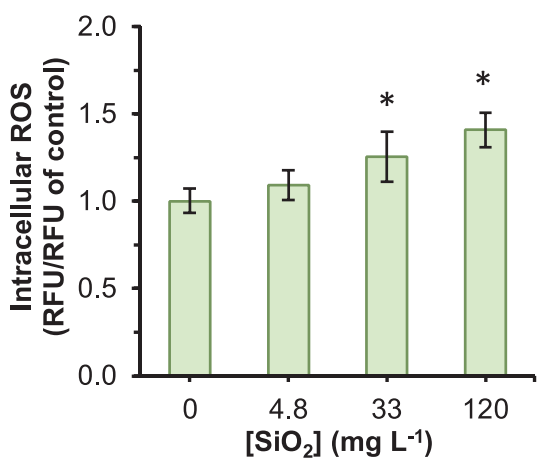

B

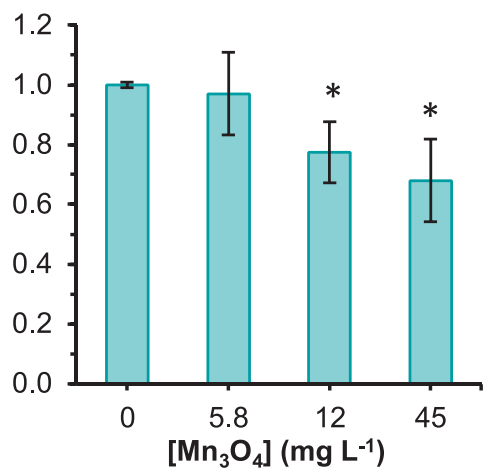

D

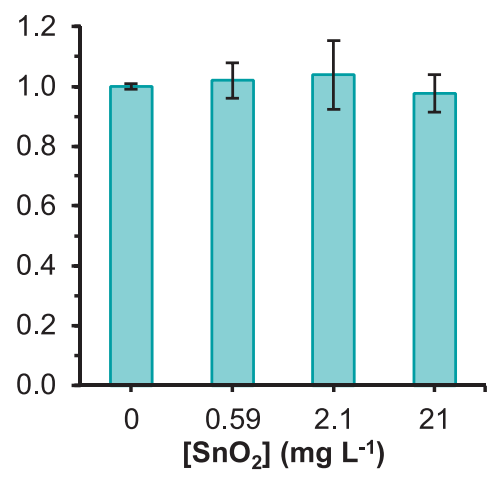

B

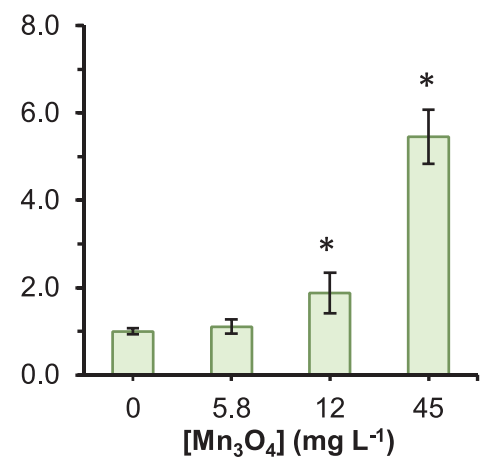

D

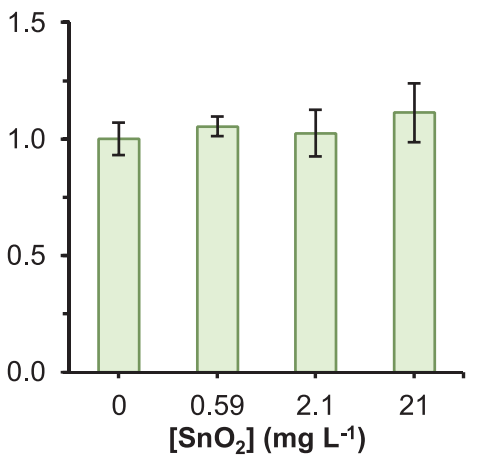

Fig. 5. Influence of the nanoparticles on the metabolic activity of $P$. subcapitata. Algal cells were incubated in the absence or presence of NPs, for $72 \mathrm{~h}$, in OECD medium. Esterase activity was evaluated by the quantification of the hydrolysis of FDA. The data are presented as mean values from at least three independent experiments; in each experiment, five fluorescent readings (in relative fluorescent units, RFUs) were taken $(n \geq 15)$. Standard deviations are presented (vertical error bars). Statistical diff ;erences were subjected to ANOVA. The means with asterisks are significantly diff ;erent $(P<0.05)$.
Fig. 6. Evaluation of intracellular ROS accumulation by $P$. subcapitata exposed to nanoparticles. Algal cells were incubated in the absence or presence of NPs, in OECD medium, for $72 \mathrm{~h}$. Intracellular accumulation of ROS was detected using $\mathrm{H}_{2}$ DCFDA. The data are presented as mean values from at least three independent experiments; in each experiment, five fluorescent readings (in relative fluorescent units, RFUs) were performed $(n \geq 15)$. Standard deviations are presented (vertical error bars). Statistical diff ;erences were subjected to ANOVA. The means with asterisks are significantly diff ;erent $(P<0.05)$. et al., 2017). Despite the agglomeration of NPs, it is unlikely that algal entrapment in these structures is the cause of the observed toxicity since alga-NP hetero-agglomerates present a loose structure (Fig. 3A). Reinforcing this possibility, it was shown that after a simple mechanical stirring of algal-NP hetero-agglomerates only $<7 \%$ of the algae remained captured in the agglomerates (Table S4).
The quantification of metal(loid)s leached from the NPs (Fig. 1C) revealed that these nanomaterials were poorly soluble in water or OCED medium. A similar solubility was described for $\mathrm{Al}_{2} \mathrm{O}_{3}$ and $\mathrm{Mn}_{3} \mathrm{O}_{4}$ NPs in OECD medium (Aruoja et al., 2015). Notwithstanding the lower solubility of $\mathrm{SnO}_{2} \mathrm{NPs}$, the amount of $\mathrm{Sn}$ ions released seems to be the main contributor of the observed toxicity. In fact, $\mathrm{SnO}_{2} \mathrm{NPs}$ presented a 
A

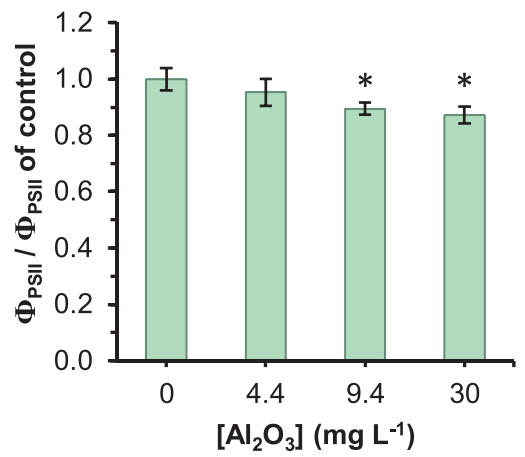

C

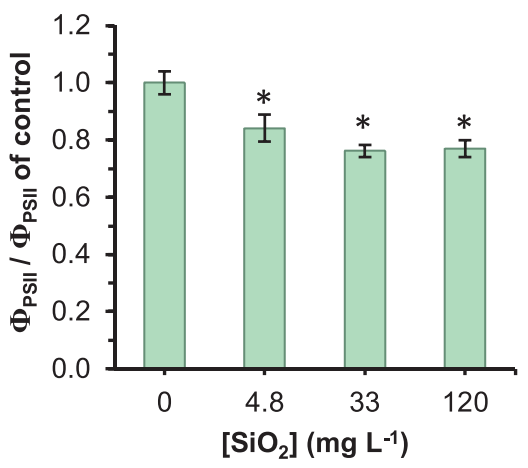

B

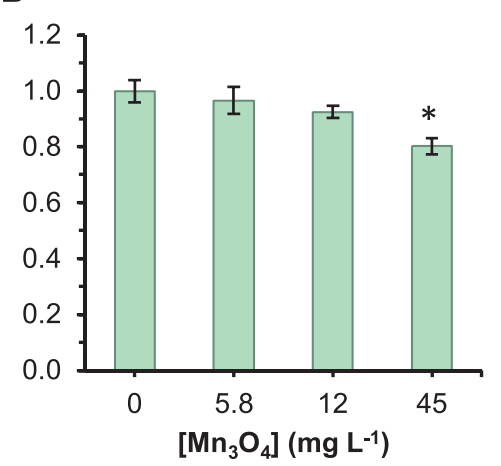

D

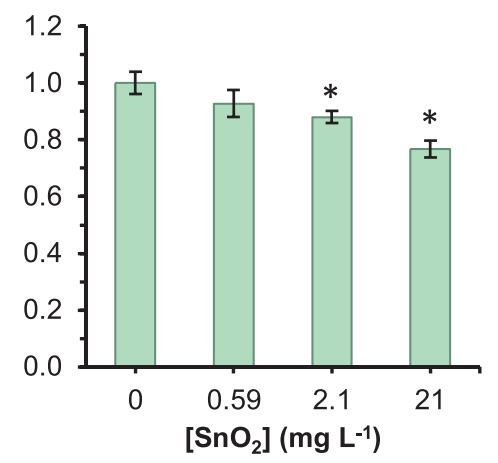

Fig. 7. Photosynthetic performance of algal cells exposed to the nanoparticles. Algal cells were incubated in absence or the presence of NPs, in OECD medium, for $72 \mathrm{~h}$. Effective photochemical quantum yield of PSII ( $\Phi_{\text {PSII }}$ ) was assessed using PAM fluorescence assay. The data are presented as mean values from at least three independent experiments, performed in duplicate $(n \geq 6)$; standard deviations are presented (vertical error bars). Statistical diff ;erences were subjected to ANOVA. The results with asterisks are significantly diff ;erent $(P<0.05)$.
$72 \mathrm{~h}-\mathrm{EC}_{50}$ value of $2.1 \mathrm{mg} \mathrm{L}^{-1}$ (Table S3). When suspended in OECD medium, $2.1 \mathrm{mg} \mathrm{L}^{-1} \mathrm{SnO}_{2} \mathrm{NPs}$ released $\sim 23 \mu \mathrm{L} \mathrm{L}^{-1} \mathrm{Sn}^{4+}$ (Fig. 1C). According to $\mathrm{Sn}^{4+}$ concentration-response toxicity curves (Fig. 2B), this metal concentration $\left(\sim 23 \mu \mathrm{g} \mathrm{L}^{-1}\right)$ should induce an inhibition of $40 \%$ of algal growth (Fig. $3 \mathrm{C}$ ). In the case of $\mathrm{Al}_{2} \mathrm{O}_{3}$ and $\mathrm{Mn}_{3} \mathrm{O}_{4}$ NPs, the ions released should have a minor influence on the observed toxicity (Fig. 3C).

The environmental risk assessment of NPs requires information about their possible adverse effects on aquatic organisms. In the present work, the ecotoxicological hazard of NPs was assessed through their impact on $P$. subcapitata using the OECD algal growth inhibition test. In the framework of EU chemical safety policy, the potential impact of all chemicals manufactured or imported in the EU, above 1 ton per year on aquatic ecosystems has to be characterized (ECHA, 2016). According to the European Commission Directive No 1272/2008, the assessment of risks in the aquatic environment can be made using algal cells and by calculating the $\mathrm{EC}_{50}$ values of toxicants through concentration-response curves (EC, 2008). Considering this directive, the impact of pollutants on aquatic systems, based on the $\mathrm{EC}_{50}$ values, can be classified as: very toxic $\left(<1 \mathrm{mg} \mathrm{L}^{-1}\right)$, toxic $\left(1-10 \mathrm{mg} \mathrm{L}^{-1}\right)$, harmful $\left(10-100 \mathrm{mg} \mathrm{L}^{-1}\right)$ and not classified/not harmful $\left(>100 \mathrm{mg} \mathrm{L}^{-1}\right.$ ). Therefore, the hazards of the NPs, evaluated through the growth inhibition test of algae, using $P$. subcapitata, can be ranked as follows: $\mathrm{SnO}_{2}\left(2.1 \mathrm{mg} \mathrm{L}^{-1}\right)$ and $\mathrm{Al}_{2} \mathrm{O}_{3}$ (9.4 $\left.\mathrm{m} \mathrm{L}^{-1}\right)$ are considered as toxic; $\mathrm{Mn}_{3} \mathrm{O}_{4}\left(12 \mathrm{mg} \mathrm{L}^{-1}\right)$ and $\mathrm{SiO}_{2}$ (33 $\left.\mathrm{mg} \mathrm{L}^{-1}\right)$ are classified as harmful and $\mathrm{In}_{2} \mathrm{O}_{3}\left(110 \mathrm{mg} \mathrm{L}^{-1}\right)$ is classified as not classified/not harmful. A similar $72 \mathrm{~h}-\mathrm{EC}_{50}$ value $\left(34.6 \mathrm{mgL}^{-1}\right.$ ) for $\mathrm{SiO}_{2}$ NPs with $P$. subcapitata was described (Aruoja et al., 2015); however, different $\mathrm{EC}_{50}$ values were described for $\mathrm{Al}_{2} \mathrm{O}_{3}$ (31 $\mathrm{mg} \mathrm{L}^{-1}$ ) and $\mathrm{Mn}_{3} \mathrm{O}_{4}\left(1.3 \mathrm{mg} \mathrm{L}^{-1}\right.$ ) (Aruoja et al., 2015); these differences in the $\mathrm{EC}_{50}$ values can be due to the use of different alga strains and/or endpoint determination (in the present work: growth yield; literature: fluorescence of algal pigment extract). Higher $72 \mathrm{~h}-\mathrm{EC}_{50}$ values were described for $\mathrm{Al}_{2} \mathrm{O}_{3}$ and $\mathrm{SiO}_{2} \mathrm{NPs}$, evaluated with other algal cells. Thus, for $\mathrm{Al}_{2} \mathrm{O}_{3}$ NPs, $72 \mathrm{~h}-\mathrm{EC}_{50}$ values of 39,45 and $100-300 \mathrm{mg} \mathrm{L}^{-1}$ for Scenedesmus sp., Chlorella sp. (Sadiq et al., 2011) and Porphyridium aerugineum Geitler (Karunakaran et al., 2015), respectively, were described. In the case of $\mathrm{SiO}_{2} \mathrm{NPs}$, a $72 \mathrm{~h}-\mathrm{EC}_{50}$ value of $1000 \mathrm{mg} \mathrm{L}^{-1}$ for the alga Porphyridium aerugineum Geitler was reported (Karunakaran et al., 2015). The higher sensitivity of $P$. subcapitata to NPs, compared to other algal genera, reinforces the significance of this alga in the ecotoxicity assessment of freshwaters.

A critical issue regarding to the NP ecotoxicity is related with the knowledge of the toxic modes of action of these nanomaterials. Through photosynthesis, algae convert light energy into chemical energy that can be further used in cellular activities. Thus, it is expected that any impact on algal photosynthesis may cause disturbance of cell functioning. The exposure of cells to $\mathrm{Al}_{2} \mathrm{O}_{3}, \mathrm{Mn}_{3} \mathrm{O}_{4}, \mathrm{SiO}_{2}$ and $\mathrm{SnO}_{2} \mathrm{NPs}$ induced a reduction of $\Phi_{\text {PSII }}$ (Fig. 7), which indicated a decrease in the light utilization efficiency of PSII of algal cells. In fact, $\Phi_{\text {PSII }}$ gives a measure of the efficiency at which light absorbed by PSII is used in photochemistry (Baker, 2008). Most likely due to the reduction of the efficiency of photosynthesis, algal cells exposed to the NPs studied should present reduced levels of ATP which, in turn, can be one of the reasons (or the main reason) of algal growth inhibition. A disturbance of photosynthesis was also described in algal cells of $P$. subcapitata exposed for $72 \mathrm{~h}$ to $\mathrm{CeO}_{2}$ or NiO NPs (Rodea-Palomares et al., 2012; Sousa et al., 2018).

The electrons that were no longer used in the photosynthesis (due to the reduction of PSII activity) could induce the production of ROS through the reduction of molecular oxygen (Rutherford and KriegerLiszkay, 2001). Compatible with this possibility, intracellular accumulation of ROS in algal cells exposed to $72 \mathrm{~h}-\mathrm{EC}_{50}$ and $72 \mathrm{~h}-\mathrm{EC}_{90}$ values of $\mathrm{Al}_{2} \mathrm{O}_{3}, \mathrm{Mn}_{3} \mathrm{O}_{4}$ or $\mathrm{SiO}_{2}$ NPs was observed (Fig. 6). Our results are in agreement with those of different authors, who reported ROS production in different model cells when exposed to $\mathrm{Al}_{2} \mathrm{O}_{3}, \mathrm{Mn}_{3} \mathrm{O}_{4}$ or $\mathrm{SiO}_{2}$ NPs. Thus, it was described that $\mathrm{Al}_{2} \mathrm{O}_{3}$ NPs caused oxidative stress in the plant Triticum aestivum (Yanik and Vardar, 2015, 2018) and in human lymphocytes (Rajiv et al., 2016); $\mathrm{Mn}_{3} \mathrm{O}_{4}$ NPs induced ROS production in rat alveolar cells (Frick et al., 2011; Urner et al., 2014) and $\mathrm{SiO}_{2}$ NPs provoked ROS production in lymphocytes (Azimipour et al., 2018), intestinal (Setyawati et al., 2015), lung and human bronchial epithelial cells (Eom and Jinhee Cho, 2011; Manke et al., 
2013).

Two of the main intracellular ROS targets are cell membrane (via oxidation of lipids) and proteins, which can be inactivated through oxidation (Valavanidis et al., 2006). The chronic exposure (up to 6 days) of algal cells to the NPs studied, even at high concentrations, did not cause the perturbation of membrane integrity (Fig. 3B). A similar result was observed with the alga Scenedesmus obliquus when exposed to $\mathrm{SiO}_{2}$ NPs (Liu et al., 2018). In relation to protein oxidation, different mechanisms were described, which includes the oxidation of amino acid residues containing aromatic side chain or sulfhydryl groups (Cecarini et al., 2007). In agreement with this possibility, the reduction of esterase activity (metabolic activity) in algal cells exposed to $\mathrm{Al}_{2} \mathrm{O}_{3}$, $\mathrm{Mn}_{3} \mathrm{O}_{4}$ or $\mathrm{SiO}_{2}$ NPs was observed (Fig. 5), which corresponded to the same NPs that caused the intracellular accumulation of ROS (Fig. 6). A similar effect (inhibition of esterase activity) was observed in alveolar and intestinal cells exposed to $\mathrm{Mn}_{3} \mathrm{O}_{4}$ NPs (Titma et al., 2016).

\section{Conclusions}

The five NPs tested were unstable in OECD algal medium (low zeta potential values) and presented tendency to agglomerate. However, these agglomerates were easily dispersed by simple agitation and had a loose structure, which makes very unlikely that the toxicity of these NPs could be due to the entrapment of the algal cells in the NP agglomerates. The NPs studied were poorly soluble in OECD medium. However, the amount of $\mathrm{Sn}^{4+}$ leached from the $\mathrm{SnO}_{2} \mathrm{NPs}$ seems to be the main contributor for the toxicity observed by this NP.

Using the algal growth inhibition test, performed with the freshwater alga $P$. subcapitata, and based on the $72 \mathrm{~h}-\mathrm{EC}_{50}$ values obtained, the hazard of the NPs were categorized as: toxic $\left(\mathrm{Al}_{2} \mathrm{O}_{3}\right.$ and $\left.\mathrm{SnO}_{2}\right)$, harmful $\left(\mathrm{Mn}_{3} \mathrm{O}_{4}\right.$ and $\left.\mathrm{SiO}_{2}\right)$ and not classified/not toxic $\left(\mathrm{In}_{2} \mathrm{O}_{3}\right)$.

The study of the impact of the NPs on algal cells using five endpoints (growth, membrane integrity, metabolic activity, photosynthetic activity and intracellular ROS accumulation) revealed that, in the case of $\mathrm{Al}_{2} \mathrm{O}_{3}, \mathrm{Mn}_{3} \mathrm{O}_{4}$ and $\mathrm{SiO}_{2}$, the algistatic effect (inhibition of algal growth in the absence of cell death - disruption of cell membrane integrity) can be attributed to the great disturbance of algal physiology: reduction of photosynthetic and metabolic activity and intracellular accumulation of ROS. Probably, the electrons not used in the photosynthesis (due to a reduction of electron flux through PSII) could lead to the induction of ROS, which, in turn, may be in the origin of the reduction of metabolic activity as a consequence of the oxidation of sensitive residues of esterases. The exposure of algal cells to $\mathrm{SnO}_{2} \mathrm{NPs}$ induced the disturbance of the functionality of PSII in the absence of intracellular ROS accumulation or loss of metabolic activity. The reduction of the capacity of algal cells to convert light energy into chemical energy (ATP) may be the cause of the algistatic effect observed.

The results presented herein reinforce the need to study the NPs, in an extended way, using ecologically relevant organisms such as the green alga $P$. subcapitata, in order to provide a systematic characterization of their potential pollutant hazards in the aquatic environment.

\section{Funding information}

This work was performed in the framework of the financing by Portuguese Foundation for Science and Technology (FCT) under the scope of the strategic funding of UID/BIO/04469/2019 unit and BioTecNorte operation (NORTE-01-0145-FEDER-000004) funded by the European Regional Development Fund under the scope of Norte2020—Programa Operacional Regional do Norte and LAQV (UID/ QUI/50006/2013-POCI/01/0145/FEDER/007265) with financial support from FCT/MEC through national funds and co-financed by FEDER, under the Partnership Agreement PT2020.

\section{Compliance with ethical standards}

This article does not contain any studies with human participants or animals performed by any of the authors.

\section{Declaration of Competing Interest}

The authors declare that they have no conflict of interest.

\section{Acknowledgments}

Cátia A. Sousa gratefully acknowledges the doctoral grant (SFRH/ $\mathrm{BD} / 101452 / 2014)$ from Portuguese Foundation for Science and Technology (FCT).

\section{Appendix A. Supplementary data}

Supplementary material related to this article can be found, in the online version, at doi:https://doi.org/10.1016/j.aquatox.2019.105265.

\section{References}

Ahamed, M., Akhtar, M.J., Khan, M.A.M., Alhadlaq, H.A., Aldalbahi, A., 2017. Nanocubes of indium oxide induce cytotoxicity and apoptosis through oxidative stress in human lung epithelial cells. Colloids Surf. B Biointerfaces 156, 157-164.

Andreescu, S., Ornatska, M., Erlichman, J.S., Estevez, A., Leiter, J.C., 2012. Biomedical applications of metal oxide nanoparticles. In: Matijević, E. (Ed.), Fine Particles in Medicine and Pharmacy. Springer, Boston, MA, pp. 57-100.

Aruoja, V., Pokhrel, S., Sihtmae, M., Mortimer, M., Madler, L., Kahru, A., 2015. Toxicity of 12 metal-based nanoparticles to algae, bacteria and protozoa. Environ. Sci. Nano 2, 630-644.

Azimipour, S., Ghaedi, S., Mehrabi, Z., Ghasemzadeh, S.A., Heshmati, M., Barikrow, N., Attar, F., Falahati, M., 2018. Heme degradation and iron release of haemoglobin and oxidative stress of lymphocyte cells in the presence of silica nanoparticles. Int. J. Biol. Macromol. 118, 800-807.

Baker, N.R., 2008. Chlorophyll fluorescence: a probe of photosynthesis in vivo. Annu. Rev. Plant Biol. 59, 89-113.

Cecarini, V., Gee, J., Fioretti, E., Amici, M., Angeletti, M., Eleuteri, A.M., Keller, J.N., 2007. Protein oxidation and cellular homeostasis: emphasis on metabolism. Biochim. Biophys. Acta 1773, 93-104.

Dorsey, J., Yentsch, C.M., Mayo, S., McKenna, C., 1989. Rapid analytical technique for the assessment of cell metabolic-activity in marine microalgae. Cytometry 10, 622-628.

EC, 2008. Classification, labelling and packaging of substances and mixtures, amending and repealing - regulation (EC) $\mathrm{n}^{\circ} 1272 / 2008$ of the European Parliament and of the Council of 16 D ecember 2008. Off. J. Eur. Union L353, 1-1355.

ECHA, 2016. Endpoint specific guidance. In: ECHA (Ed.), Guidance on Information Requirements and Chemical Safety Assessment. European Chemicals Agency, Helsinki, Finland.

Eom, H.-J., Jinhee Cho, J., 2011. $\mathrm{SiO}_{2}$ nanoparticles induced cytotoxicity by oxidative stress in human bronchial epithelial cell, Beas-2B. Environ. Health Toxicol. 26, 1-7.

Frick, R., Muller-Edenborn, B., Schlicker, A., Rothen-Rutishauser, B., Raemy, D.O., Gunther, D., Hattendorf, B., Stark, W., Beck-Schimmer, B., 2011. Comparison of manganese oxide nanoparticles and manganese sulfate with regard to oxidative stress, uptake and apoptosis in alveolar epithelial cells. Toxicol. Lett. 205, 163-172.

Geis, S.W., Fleming, K.L., Korthals, E.T., Searle, G., Reynolds, L., Karner, D.A., 2000. Modifications to the algal growth inhibition test for use as a regulatory assay. Environ. Toxicol. Chem. 19, 36-41.

Genty, B., Briantais, J.M., Baker, N.R., 1989. The relationship between the quantum yield of photosynthetic electron transport and quenching of chlorophyll fluorescence. Biochim. Biophys. Acta 990, 87-92.

Hanaor, D., Michelazzi, M., Leonelli, C., Sorrell, C.C., 2012. The effects of carboxylic acids on the aqueous dispersion and electrophoretic deposition of $\mathrm{ZrO}_{2}$. J. Eur. Ceram. Soc. $32,235-244$.

Hasegawa, G., Shimonaka, M., Ishihara, Y., 2012. Differential genotoxicity of chemical properties and particle size of rare metal and metal oxide nanoparticles. J. Appl. Toxicol. 32, 72-80.

Hirner, A.V., Flaßbeck, D., 2005. Speciation of silicon. In: Cornelis, R., Crews, H., Caruso, J., Heumann, K.G. (Eds.), Handbook of Elemental Speciation II - Species in the Environment, Food, Medicine and Occupational Health. John Wiley \& Sons, Ltd, Chichester, UK, pp. 366-377.

Iler, R.K., 1978. The occurrence, dissolution, and deposition of silica. In: Iler, R.K. (Ed.), The Chemistry of Silica: Solubility, Polymerization, Colloid and Surface Properties, and Biochemistry. John Wiley \& Sons, Ltd, New York, USA, pp. 3-115.

Jeong, J., Kim, J., Seok, S.H., Cho, W.S., 2016. Indium oxide $\left(\mathrm{In}_{2} \mathrm{O}_{3}\right)$ nanoparticles induce progressive lung injury distinct from lung injuries by copper oxide $(\mathrm{CuO})$ and nickel oxide (NiO) nanoparticles. Arch. Toxicol. 90, 817-828.

Juneau, P., Popovic, R., 1999. Evidence for the rapid phytotoxicity and environmental stress evaluation using the PAM fluorometric method: importance and future application. Ecotoxicology 8, 449-455. 
Karunakaran, G., Suriyaprabha, R., Rajendran, V., Kannan, N., 2015. Toxicity evaluation based on particle size, contact angle and zeta potential of $\mathrm{SiO}_{2}$ and $\mathrm{Al}_{2} \mathrm{O}_{3}$ on the growth of green algae. Adv. Nano Res. 3, 243-255.

Laurent, S., Boutry, S., Müller, R.N., 2018. Metal oxide particles and their prospects for applications. In: Mahmoudi, M., Laurent, S. (Eds.), Iron Oxide Nanoparticles for Biomedical Applications: Synthesis, Functionalization and Application. Elsevier, Ltd, pp. 3-42.

Liu, Y.H., Wang, S., Wang, Z., Ye, N., Fang, H., Wang, D.G., 2018. $\mathrm{TiO}_{2}, \mathrm{SiO}_{2}$ and $\mathrm{ZrO}_{2}$ nanoparticles synergistically provoke cellular oxidative damage in freshwater microalgae. Nanomaterials $8,1-12$.

Machado, M.D., Soares, E.V., 2012. Development of a short-term assay based on the evaluation of the plasma membrane integrity of the alga Pseudokirchneriella subcapitata. Appl. Microbiol. Biotechnol. 95, 1035-1042.

Machado, M.D., Soares, E.V., 2013. Optimization of a microplate-based assay to assess esterase activity in the alga Pseudokirchneriella subcapitata. Water Air Soil Pollut. 224, 1-9.

Machado, M.D., Soares, E.V., 2016. Short- and long-term exposure to heavy metals induced oxidative stress response in Pseudokirchneriella subcapitata. Clean Soil Air Water 44, 1578-1583.

Manke, A., Wang, L., Rojanasakul, Y., 2013. Mechanisms of nanoparticle-induced oxidative stress and toxicity. Biomed. Res. Int. 2013, 1-15.

Manzo, S., Buono, S., Rametta, G., Miglietta, M., Schiavo, S., Di Francia, G., 2015. The diverse toxic effect of $\mathrm{SiO}_{2}$ and $\mathrm{TiO}_{2}$ nanoparticles toward the marine microalgae Dunaliella tertiolecta. Environ. Sci. Pollut. Res. 22, 15941-15951.

Nanotech, 2015. Aluminium oxide: forecast from 2010 to 2025. Nanoparticles. Future Markets Inc., Edinburgh.

Ng, A.M.C., Guo, M.Y., Leung, Y.H., Chan, C.M.N., Wong, S.W.Y., Yung, M.M.N., Ma, A.P.Y., Djurisic, A.B., Leung, F.C.C., Leung, K.M.Y., Chan, W.K., Lee, H.K., 2015. Metal oxide nanoparticles with low toxicity. J. Photochem. Photobiol. B 151, 17-24.

OECD, 2011. Test № 201: Freshwater Alga and Cyanobacteria, Growth Inhibition Test. OECD Guidelines for the Testing of Chemicals. Section 2. OECD Publishing, Paris. https://doi.org/10.1787/9789264069923-en.

Rajiv, S., Jerobin, J., Saranya, V., Nainawat, M., Sharma, A., Makwana, P., Gayathri, C., Bharath, L., Singh, M., Kumar, M., Mukherjee, A., Chandrasekaran, N., 2016. Comparative cytotoxicity and genotoxicity of cobalt (II, III) oxide, iron (III) oxide, silicon dioxide, and aluminium oxide nanoparticles on human lymphocytes in vitro. Hum. Exp. Toxicol. 35, 170-183.

Rodea-Palomares, I., Gonzalo, S., Santiago-Morales, J., Leganes, F., Garcia-Calvo, E., Rosal, R., Fernandez-Pinas, F., 2012. An insight into the mechanisms of nanoceria toxicity in aquatic photosynthetic organisms. Aquat. Toxicol. 122, 133-143.

Rogers, N.J., Franklin, N.M., Apte, S.C., Batley, G.E., Angel, B.M., Lead, J.R., Baalousha,
M., 2010. Physico-chemical behaviour and algal toxicity of nanoparticulate $\mathrm{CeO}_{2}$ in freshwater. Environ. Chem. 7, 50-60.

Rutherford, A.W., Krieger-Liszkay, A., 2001. Herbicide-induced oxidative stress in photosystem II. Trends Biochem. Sci. 26, 648-653.

Sadiq, I.M., Pakrashi, S., Chandrasekaran, N., Mukherjee, A., 2011. Studies on toxicity of aluminum oxide $\left(\mathrm{Al}_{2} \mathrm{O}_{3}\right)$ nanoparticles to microalgae species: Scenedesmus sp and Chlorella sp. J. Nanopart. Res. 13, 3287-3299.

Setyawati, M.I., Tay, C.Y., Leong, D.T., 2015. Mechanistic investigation of the biological effects of $\mathrm{SiO}_{2}, \mathrm{TiO}_{2}$, and $\mathrm{ZnO}$ nanoparticles on intestinal cells. Small 11, 3458-3468.

Sousa, C.A., Soares, H.M.V.M., Soares, E.V., 2018. Toxic effects of nickel oxide (NiO) nanoparticles on the freshwater alga Pseudokirchneriella subcapitata. Aquat. Toxicol. 204, 80-90.

Tarpey, M.M., Wink, D.A., Grisham, M.B., 2004. Methods for detection of reactive metabolites of oxygen and nitrogen: in vitro and in vivo considerations. Am. J. Physiol. Regul. Integr. Comp. Physiol. 286, R431-R444.

Tian, Z.-Y., Kouotou, P.M., Bahlawane, N., Ngamou, P.H.T., 2013. Synthesis of the catalytically active $\mathrm{Mn}_{3} \mathrm{O}_{4}$ spinel and its thermal properties. J. Phys. Chem. C 117 , 6218-6224.

Titma, T., Shimmo, R., Siigur, J., Kahru, A., 2016. Toxicity of antimony, copper, cobalt, manganese, titanium and zinc oxide nanoparticles for the alveolar and intestinal epithelial barrier cells in vitro. Cytotechnology 68, 2363-2377.

Urner, M., Schlicker, A., Z'Graggen, B.R., Stepuk, A., Booy, C., Buehler, K.P., Limbach, L., Chmiel, C., Stark, W.J., Beck-Schimmer, B., 2014. Inflammatory response of lung macrophages and epithelial cells after exposure to redox active nanoparticles: effect of solubility and antioxidant treatment. Environ. Sci. Technol. 48, 13960-13968.

US-EPA, 2002. Short-Term Methods for Estimating the Chronic Toxicity of Effluents and Receiving Waters to Freshwater Organisms, 4th ed. Environmental Protection Agency, Washington, DC, pp. 1-350 EPA-821-R-302-013.

Valavanidis, A., Vlahogianni, T., Dassenakis, M., Scoullos, M., 2006. Molecular biomarkers of oxidative stress in aquatic organisms in relation to toxic environmental pollutants. Ecotoxicol. Environ. Saf. 64, 178-189.

Vranic, S., Shimada, Y., Ichihara, S., Kimata, M., Wu, W., Tanaka, T., Boland, S., Tran, L., Ichihara, G., 2019. Toxicological evaluation of $\mathrm{SiO}_{2}$ nanoparticles by zebrafish embryo toxicity test. Int. J. Mol. Sci. 20, 1-12.

Wang, Y.L., Ding, L., Yao, C.J., Li, C.C., Xing, X.J., Huang, Y.A., Gu, T.J., Wu, M.H., 2017. Toxic effects of metal oxide nanoparticles and their underlying mechanisms. Sci. China Mat. 60, 93-108.

Yanik, F., Vardar, F., 2015. Toxic effects of aluminum oxide $\left(\mathrm{Al}_{2} \mathrm{O}_{3}\right)$ nanoparticles on root growth and development in Triticum aestivum. Water Air Soil Pollut. 226, 1-12.

Yanik, F., Vardar, F., 2018. Oxidative stress response to aluminum oxide $\left(\mathrm{Al}_{2} \mathrm{O}_{3}\right)$ nanoparticles in Triticum aestivum. Biologia 73, 129-135. 